\title{
Analysis of the Effect of Gender, High School Origin, Middle School Department, College Motivation on Academic Achievement of Students of Accounting and Finance Department: Case Study on One of Private University in Indonesia
}

\author{
Michael Angelus $^{1 *}$, Armanto Witjaksono ${ }^{2}$ \\ ${ }^{1,2}$ Accounting Department, Faculty of Economics and Communication \\ Bina Nusantara University \\ Jakarta 11480, Indonesia \\ michael.angelus@binus.edu; armanto@binus.ac.id \\ *Correspondence: michael.angelus@binus.edu
}

\begin{abstract}
This research aims to know the learning patterns and student's abilities in education performance by identify and analyze the influence of gender, high school origin, middle school department, and college motivation on academic achievement. The methods of data collection are carried out through the following methods of questionnaires as the primary data and systematic literature review as secondary data. This study is quantitative explanatory and retrieves important accounting items. Based on the result of data analysis, the results showed that gender, middle school department, and college motivation are not significantly affected in the GPA While the origin of high school significantly affects the GPA. This study suggested that future studies adopt other methods of data analysis and take the dependent variable other than academic achievement.
\end{abstract}

Keywords: Academic Achievements; Gender; High School Origin; High School Programs; College Motivation; Accounting Education.

\section{INTRODUCTION}

The rise of advanced technology in 4.0 era has created several new things based on innovative idea to improve the quality of human being, but unfortunately, it would cause disruption if the society were not ready to adapt to changes. According to Albrech (2000) there are many reasons that make accounting unable to survive in the future. Frey \& Osborne, (2017) stated that of the 700 professions surveyed, 30 professions will experience vulnerability, where one of them is accountant profession. One of the main reasons is because the number of students graduating in accounting has decreased, the accounting education model is starting to be abandoned, and students will choose other majors after completing their studies (Albrech, 2000). The other reason is due to the existence of digital globalization which is an aspect of threat for students who think that the accounting in the future will be replaced by a modern systematization, where the accounting education model need to be updated to anticipate the gap between student and the digital growth (Raguseo, 2018; Rezaee \& Wang, 2019)importance and content of Big Data educational skills and topics for forensic accounting education to effectively respond to challenges and opportunities in the age of Big Data. Findings: Results indicate that the demand for and interest in Big Data/data analytics and forensic accounting will continue to increase; Big Data/data analytics and forensic accounting should be integrated into the business curriculum; many of the suggested Big Data topics should be integrated into forensic accounting education; and some attributes and techniques of Big Data are important in improving forensic accounting education and practice. Research limitations/implications: Readers should interpret 
the results with caution because of the sample size (95 academics and 103 practitioners.

Based on the American Accounting Association (AAA) reports Schools of Accountancy at US Colleges and Universities: Status and Trends 1993-2004, says that Schools of Accountancy has recorded a decreasing number from 2004, as more people retired than those who replacement. but the number of students enrolled has increased by more than $12 \%$. As a result of these changes, teachers and students must be able to cooperate to increase their contribution by improve the quality of accounting education model through technology, where it can meet the needs to develop new skills and gain learning opportunities on a broader and more flexible scale, which can raise their knowledge continuously in order to sustain the accounting education. Some of these things certainly raise many questions, one of which is whether the education of accounting will survive and sustainable in the future. Therefore, this study focuses on the topic of accounting education to explore knowledge related to things that can encourage the survival of accounting in the future.

According to Baeten et al. (2010: 252), students from various disciplines from each country, the learning approaches they use are also different. Therefore, this research is on students who specialize in accounting, where the data obtained can be used by the accounting department to encourage improvement in the quality and quantity of accounting in the future. According to Bastian (2006) based on the book Accounting for Education that in terms of the quality of education, Indonesia is the worst of the 12 Asian and ASEAN countries, which is characterized by the delay in the quality of accounting education, the lack of support from parents and universities to facilitate educational programs in accordance with the change of times, so the impact translates into students who do not have the disposition and openness to face change.

This condition is the impact of the right approach, in which the central government establishes a national curriculum, exams, procedures, staff, teacher assignments throughout Indonesia. One way to maintain accounting education is through academic achievement research, which is an important issue for all university stakeholders, and academic achievement surveys for universities, faculty and students, and academic achievement can be effective in the development of policies relating to student admission programs and at the same time, the same. change in teaching power Lee et al., (2017).

Based on data from the Malaysian Ministry of Education (2000) reveals that women in Malaysia have consistently outperformed men in general exams at primary, lower secondary, and upper secondary levels in science, English, Malay, and mathematics over five years. (Clear \& Dahan, 2010: 721). Clear and Dahan then conducted a study that combined data on schools, enrollment, and students whose results showed differences between the two.

According to Lee et al., (2017) explained how an educational system needs to innovate by building a new education model framework that can improve the learning process by adapting to the times, so this will transform students and teachers to obtain new experiences that are more flexible. Then in Lalima \& Lata Dangwal, (2017) how innovation is able to find new opportunities to improve students ability and quality to think and act, so that it can prepare them to be able to contribute to the world of society in a superior way. This shows by creating the latest innovative advancements can empower and adapt students to develop their potential skills through education (Sorescu, 2017).

Finally, we can conclude, high school accounting and college motivation are important things for every student. Because students before choosing to enter university, they will evaluate based on their high school specialization, and the question also arises whether they really want to go to university or the fact that the difficulties they face in continuing university. Therefore, based on the facts related to the importance of accounting education in the present and in the future.

\section{METHODS}

This research is using explanatory quantitative method, where according to Creswell, (2007) The explanatory quantitative is a process that is carried out in research to find information by obtaining factual data through statistics or numbers to analyze and identify relevant information. The studied population consists of one of private university students currently attending the third and fifth semester, where researcher obtain the all the data and information by distributed questionnaire as the primary data and for the secondary from journal and e-books in the library. The techniques used in this research are as follows. Questionnaires, which are a series of questions formulated and arranged in such a way that respondents can answer (Priatna, 2008). The questionnaire in this 
study was organized in the form of closed questions so that respondents would only provide answers by writing an "X" cross for the answer they deemed most suitable for the respondent. related to gender theory, delivery of material by teachers, domicile, and career choices.

Sampling research using probabilistic sampling technique with simple random sampling method (simple random sampling). Probabilistic sampling is a sampling method that ensures that every member of the population has an equal opportunity to be taken as a sample. This method is best used when the main purpose of the study is to generalize the results to the entire population (Sekaran \& Bougie, 2013: 256).

The simple random sampling method is used because each member of the population has the same opportunity to be involved, where this method is used in uncomplicated and not too heterogeneous populations (Lungan, 2006: 196). This type of sampling design has the advantages of higher accuracy (less bias information), universally acceptable results, and good generalizability to accumulate and process the data into relevant information.

The collected data was analyzed using the SPSS (Statistical Package for Social Sciences) application 20 (Hanafi \& Fadilah, 2017). SPSS is a program used to statistically process research data. The tests were performed on 320 samples from Slovin's formula calculation plus another 40 samples obtained using validity and reliability tests, normality tests, classical hypothesis tests and multiple regression analysis. The tests carried out in this study (for data quality test) were Validity and Reliability Test, Classic Assumption Test, Normality Test, Multicollinearity Test, Correlation Analysis, Heteroskedasticity Test. For Hypothesis testing the tests performed are Multiple Linear Analysis Test, Coefficient of Determination, Simultaneous Test, and t Test.

\section{RESULT AND DISCUSSION}

\section{DESCRIPTIVE STATISTICS}

Table 1. Descriptive Statistic of variables measurement

\begin{tabular}{clll}
\hline \multirow{2}{*}{ Variables } & Measurement & Freq & Percentages \\
\hline \multirow{2}{*}{ GEN } & 0 (Male) & 115 & $36.14 \%$ \\
& 1 (Female) & 205 & $63.86 \%$ \\
\hline \multirow{2}{*}{ HSO } & 0 (Private) & 112 & $34.89 \%$ \\
& 1 (Public) & 208 & $65.11 \%$ \\
\hline \multirow{2}{*}{ MSD } & 0 (Science) & 118 & $37.07 \%$ \\
& 1 (Social) & 202 & $62.93 \%$ \\
\hline
\end{tabular}

Based on the table 1 above, the authors were using 3 codes of Variables like GEN refers to Gender, HSO refers to the type of the High School Origin, and MSD refers to the Middle School Department. Most of the respondents are women from private schools that accept social services. It indicates how most accounting students are women who come from public schools that were taking social classes.

Table 2. Data Statistics

\begin{tabular}{lccc}
\hline & & CM & GPA \\
\hline \multirow{2}{*}{$\mathbf{N}$} & Valid & $\mathbf{3 2 0}$ & $\mathbf{3 2 0}$ \\
\cline { 2 - 4 } & Missing & $\mathbf{0}$ & $\mathbf{0}$ \\
\hline Mean & 3.0809 & 2.9954 \\
\hline Median & 3.0417 & 3.0500 \\
\hline Mode & 3.00 & 3.20 \\
\hline Minimum & 2.25 & 1.20 \\
\hline Maximum & 4.38 & 4.00 \\
\hline
\end{tabular}

The following is a table 2 about descriptive statistics describing the mean, median, mode, maximum and minimum of each variable. The following is a table of Descriptive Statistics that describes the mean, the median, the mode, the maximum, and the minimum of each variable to be processed. All the samples obtained were 320 , which is more than the minimum number required in the calculation of Slovin's formula. 
In this research, the authors are using 4 independent variables (X) that consist of Gender (X1), high school origin (X2), middle school department (X3), and College Motivation (X4), where the dependent variable (Y) is Academic Achivement (GPA).

The average is the average value of the overall data, which is obtained by adding all the data, then dividing by the number of data processed. In College Motivation (CM) the result is 3.08 and in GPA it is 2.99.

The median is the mean value of all data, in the college motivation (CM) the result is 3.04 and, in the GPA, it's 3.05 and Mode is the data value that appears most often, in College Motivation (CM) the result is 3.00 and in GPA it is 3.20 The pass score for MK is 2.25 and the pass score for GPA is 1.20. while the maximum value for the Constitutional Court is 4.38 and the GPA is 4.00 .

\section{Validity and Reliability test}

Validity and Reliability Test This validity and reliability test is only carried out on the College Motivation (CM) variable because the $\mathrm{CM}$ variable has more than one question, so it must be tested whether all the questions asked are able to measure the independent variable in question. The validity test aims to determine the level of validity of all data obtained in the research (Sugiyono, 2015). The reliability test is an instrument to measure the level of consistency, where the higher the reliability coefficient reaches one, the more reliable (Octaryani \& Baidun, 2018). Degree of freedom (df) is the amount of freedom a person has in taking samples. The formula to is $\mathrm{df}=\mathrm{n}-2$, then about the result for this study can be calculated with the formula of $\mathrm{df}=320-2=318$. The error rate in this study uses $(\alpha=5 \% / 0.05)$ which means the confidence level is $95 \%$, this explains that the comparison of the error rate in the experiment is 1:20 where 1 time error in 20 trials. The result of $t$ table obtained through SPSS, is 1.65 , then this number is used to calculate $r$ table with the formula $t / S Q R T ~\left(318+t^{* *} 2\right)$ using SPSS, and then the result of $r$ table is 0.09 . Then the results of this $r$ are compared with $r$ which is calculated from each of the tested questions.

Table 3. Item-Total Statistics

\begin{tabular}{|c|c|c|c|c|c|}
\hline & $\begin{array}{l}\text { Scale Mean if } \\
\text { Item Deleted }\end{array}$ & $\begin{array}{l}\text { Scale Variance } \\
\text { if Item Deleted }\end{array}$ & $\begin{array}{c}\text { Corrected } \\
\text { Item-Total } \\
\text { Correlation }\end{array}$ & $\begin{array}{c}\text { Squared } \\
\text { Multiple } \\
\text { Correlation }\end{array}$ & $\begin{array}{l}\text { Cronbach's } \\
\text { Alpha if Item } \\
\text { Deleted }\end{array}$ \\
\hline M1 & 67.2594 & 70.105 & .120 & .160 & .686 \\
\hline $\mathrm{M} 2$ & 68.2531 & 66.340 & .385 & .280 & .666 \\
\hline M3 & 67.8063 & 70.169 & .126 & .327 & .686 \\
\hline M4 & 68.9219 & 66.392 & .338 & .457 & .669 \\
\hline M5 & 67.7688 & 71.188 & .095 & .109 & .694 \\
\hline M6 & 69.0375 & 66.525 & .289 & .375 & .672 \\
\hline M7 & 68.5250 & 68.357 & .183 & .474 & .682 \\
\hline M8 & 68.7469 & 62.039 & .545 & .796 & .647 \\
\hline M9 & 68.4875 & 65.868 & .268 & .450 & .674 \\
\hline M10 & 67.1375 & 68.972 & .231 & .303 & .678 \\
\hline M11 & 68.8656 & 66.556 & .300 & .346 & .672 \\
\hline M12 & 68.5906 & 68.951 & .198 & .477 & .680 \\
\hline M13 & 68.2781 & 68.151 & .175 & .450 & .684 \\
\hline M14 & 68.6250 & 67.840 & .257 & .493 & .676 \\
\hline M15 & 69.1031 & 64.889 & .450 & .556 & .659 \\
\hline M16 & 68.7500 & 62.740 & .489 & .753 & .652 \\
\hline M17 & 67.1500 & 70.291 & .110 & .251 & .687 \\
\hline M18 & 68.9375 & 68.473 & .159 & .223 & .685 \\
\hline M19 & 68.0938 & 69.201 & .167 & .292 & .683 \\
\hline M20 & 67.9563 & 71.434 & .098 & .288 & .695 \\
\hline M21 & 69.5156 & 67.454 & .277 & .519 & .674 \\
\hline M22 & 68.3125 & 70.404 & .113 & .108 & .695 \\
\hline M23 & 67.6500 & 66.949 & .233 & .240 & .678 \\
\hline M24 & 68.9906 & 65.846 & .339 & .328 & .668 \\
\hline
\end{tabular}


Table 4. Validity Conclusion Test

\begin{tabular}{|c|c|c|c|}
\hline M & R count & R table & Conclusion \\
\hline M1 & .120 & .09 & Valid \\
\hline M2 & .385 & .09 & Valid \\
\hline M3 & .126 & .09 & Valid \\
\hline M4 & .338 & .09 & Valid \\
\hline M5 & .095 & .09 & Valid \\
\hline M6 & .289 & .09 & Valid \\
\hline M7 & .183 & .09 & Valid \\
\hline M8 & .545 & .09 & Valid \\
\hline M9 & .268 & .09 & Valid \\
\hline M10 & .231 & .09 & Valid \\
\hline M11 & .300 & .09 & Valid \\
\hline M12 & .198 & .09 & Valid \\
\hline M13 & .175 & .09 & Valid \\
\hline M14 & .257 & .09 & Valid \\
\hline M15 & .450 & .09 & Valid \\
\hline M16 & .489 & .09 & Valid \\
\hline M17 & .110 & .09 & Valid \\
\hline M18 & .159 & .09 & Valid \\
\hline M19 & .167 & .09 & Valid \\
\hline M20 & .098 & .09 & Valid \\
\hline M21 & .277 & .09 & Valid \\
\hline M22 & .113 & .09 & Valid \\
\hline M23 & .233 & .09 & Valid \\
\hline M24 & .339 & .09 & Valid \\
\hline
\end{tabular}

From these results that has been received and calculated, all the questions are valid, where the amount has reached the minimum amount, therefore the next step is to see if the data is reliable. Here are the results of the reliability test on the $\mathrm{CM}$ variable.

Table 5. Reliability Test

\begin{tabular}{cc}
\hline \multicolumn{2}{c}{ Reliability Statistics } \\
\hline Cronbach's Alpha & N of Items \\
\hline .686 & 24 \\
\hline
\end{tabular}

The results of the reliability test are $0.686(68.6 \%)$ where the results obtained are reliable and show the consistency of the data values obtained in each variable, so based on the results of this test, it can be declared reliable data.

The conclusion of these two tests is that the $\mathrm{CM}$ variable has passed the validity and reliability tests. Therefore, if the data is valid and reliable then the regression analysis can be performed without errors. 
Table 6. Normality Test

\begin{tabular}{|c|c|c|c|}
\hline \multicolumn{4}{|c|}{$\begin{array}{c}\text { One - Sample Kolmogorov Smirnov } \\
\text { Kolmogorov - Smirnov Test }\end{array}$} \\
\hline & & CM & GPA \\
\hline $\mathrm{N}$ & & 320 & 320 \\
\hline \multirow{2}{*}{ Normal Parameters ${ }^{\mathrm{a}, \mathrm{b}}$} & Mean & 3.0809 & 2.9954 \\
\hline & Std. Deviation & .33028 & .51346 \\
\hline \multirow{3}{*}{ Most Extreme Differences } & Absolute & .069 & .070 \\
\hline & Positive & .069 & .036 \\
\hline & Negative & -.046 & -.070 \\
\hline Kolmogorov-Smirnov Z & & 1.243 & 1.260 \\
\hline Asymp. Sig. (2-tailed) & & .091 & .083 \\
\hline \multicolumn{4}{|l|}{ a. Test distribution is Normal. } \\
\hline
\end{tabular}

Based on the view in the table above, the numbers taken for comparison are probability values, namely the Asymp number Sig. (2-tailed). The CM variable has a CM probability value of 0.091 , which is above 0.05 , so it can be concluded that the data is normally distributed.

For the GPA, based on the results in the table above, it shows that the GPA has a probability value of 0.083 which is above 0.05 , so it can be concluded that the GPA data is normally distributed.

Normal distributed data means that the processed data has a value that is close to the average at most. That is, the number of extreme data which is the lowest and the highest is small. An example is in terms of GPA, in the descriptive statistics above, the maximum GPA is 4.00 and the minimum GPA is 1.20, these two GPAs are examples of extreme data, both of which are not widely used in this study, but it is said in descriptive statistics that the mean is 2.99 . This means that if the data is normal, then a lot of data is close to the 2.99 value.

If the data is normally distributed when depicted in a graph, it will be shaped like a mountain, i.e., high data will be in the middle while the right and left have lower values.

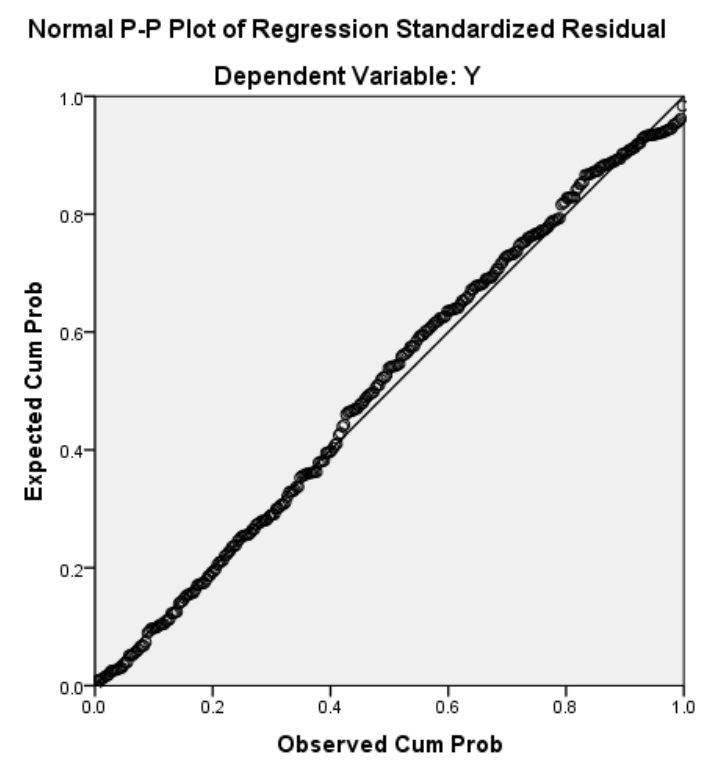

Figure 1. Normal P-P Plot of Regression Test

Based on the results of theregression test, it can be concluded how the test of the variable $Y$ with the data obtained from the respondents indicated that it was valid and could be used as information to support explanations related to the research topic. 


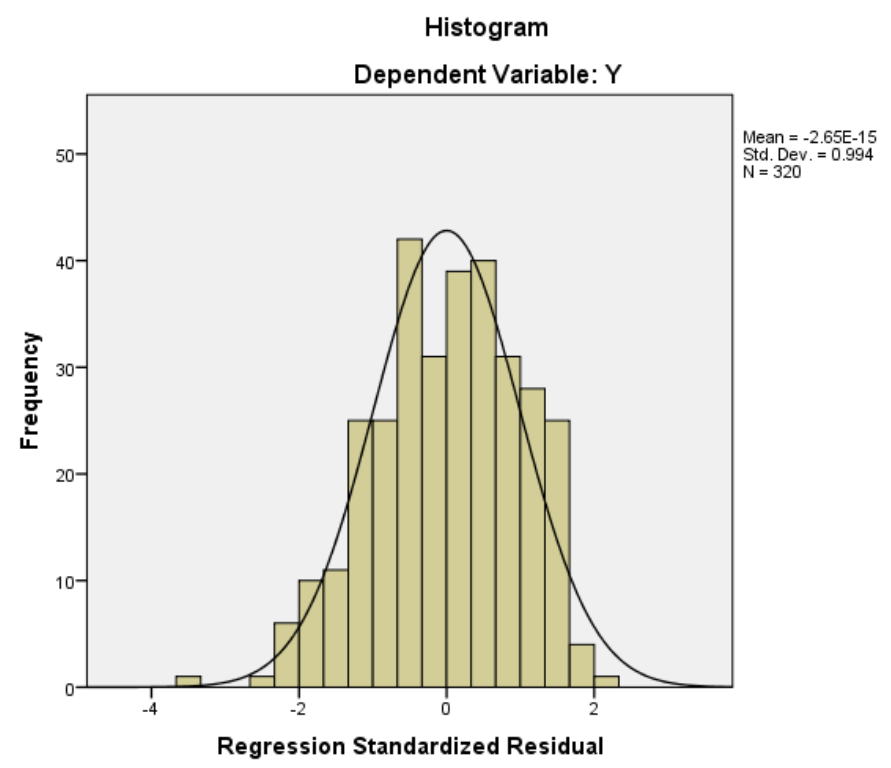

Figure 2. Regression Test

This means that the three data variables used have passed the normality test, which means that the three data are normally distributed.

\section{Multicollinearity Test}

The analysis used to test the independent variable that is more than 1 is the multicollinearity test, this test is used because when using simple linear regression, it can't measure the relationship between all independent variables. Multicollinearity test is used to analyze the correlation matrix between the independent variables and calculating the tolerance and VIF values.

The regression equation for the multicollinearity test in this study is formulated in:

$$
\mathrm{GPA}=\mathrm{b} 0+\mathrm{b} 1 \mathrm{GEN}+\mathrm{b} 2 \mathrm{HSO}+\mathrm{b} 3 \mathrm{MSD}+\mathrm{b} 4 \mathrm{CM}
$$

Table 7. Multicollinearity Test

\begin{tabular}{|c|c|c|c|c|c|c|}
\hline \multicolumn{7}{|c|}{ Coefficients } \\
\hline & \multirow{2}{*}{$\begin{array}{c}\text { Model } \\
\text { B }\end{array}$} & \multicolumn{2}{|c|}{ Unstandardized Coefficients } & \multirow[t]{2}{*}{$\begin{array}{c}\text { Standardized } \\
\text { Coefficients }\end{array}$} & \multirow[t]{2}{*}{$\mathbf{t}$} & \multirow[t]{2}{*}{ Sig. } \\
\hline & & Std. Error & Beta & & & \\
\hline \multirow{5}{*}{1} & (Constant) & 3.083 & .273 & & 11.286 & .000 \\
\hline & GEN & .027 & .060 & .025 & .449 & .654 \\
\hline & $\mathrm{HSO}$ & .148 & .062 & .138 & 2.401 & .017 \\
\hline & MSD & -.055 & .061 & -.051 & -.895 & .372 \\
\hline & $\mathrm{CM}$ & -.054 & .087 & -.035 & -.620 & .536 \\
\hline \multicolumn{7}{|c|}{ Coefficients } \\
\hline \multirow{2}{*}{\multicolumn{2}{|c|}{ Model }} & \multicolumn{3}{|c|}{ Correlations } & \multicolumn{2}{|c|}{ Collinearity Statistics } \\
\hline & & Zero-order & Partial & Part & Tolerance & VIF \\
\hline \multirow{5}{*}{1} & (Constant) & & & & & \\
\hline & GEN & .018 & .025 & .025 & .989 & 1.011 \\
\hline & $\mathrm{HSO}$ & .123 & .134 & .134 & .947 & 1.056 \\
\hline & MSD & -.026 & -.050 & -.050 & .940 & 1.063 \\
\hline & $\mathrm{CM}$ & -.035 & -.035 & -.035 & .992 & 1.008 \\
\hline
\end{tabular}


The calculation results in the table above show that the GEN variable has a tolerance value of 0.989 and a VIF value of 1.011, HSO has a tolerance value of 0.947 and a VIF value of 1.056, MSD has a tolerance value of 0.940 and a VIF value of 1.063, CM has a tolerance value of 0.992 and a VIF value 1.008 . Therefore, it can be concluded that none of the independent variables in this study had a tolerance value $<=0.10$ and a VIF value $>=$ 0.10 . So it can be concluded that there is no multicollinearity in the data information.

\section{Autocorrelation Test}

The autocorrelation test aims to test whether in the linear regression model there is a correlation between the confounding error in the t-1 period (previous), it is usually found when the time series data or data involving many periods used in this study is the Run Test test.

Table 8. Autocorrelation Test

\begin{tabular}{lcccc}
\hline \multicolumn{5}{c}{ Runs Test } \\
\hline & GEN & HSO & MSD & CM \\
\hline Test Value $^{\mathrm{a}}$ & 1.00 & 1.00 & 1.00 & 3.04 \\
\hline Cases $<$ Test Value $^{\circ}$ & 116 & 112 & 119 & 151 \\
\hline Cases $>=$ Test Value & 204 & 208 & 201 & 169 \\
\hline Total Cases & 320 & 320 & 320 & 320 \\
\hline Number of Runs & 131 & 121 & 137 & 171 \\
\hline Z & -2.169 & -3.151 & -1.618 & 1.180 \\
\hline Asymp. Sig. (2-tailed) & .030 & .006 & .106 & .238 \\
\hline a. Median & & & & \\
\hline
\end{tabular}

Based on the data in table 8, the significant value for the GN variable is 0.030 , for the HSO variable it is 0.006 , for the MSD variable it is 0.106 and for the $\mathrm{CM}$ variable it is 0.238 . After obtaining the Run Test, the next step is to test the existing hypothesis, because the two variables have a significant value of more than 0.05 , meaning that it can be concluded that there is no autocorrelation.

\section{Heteroscedasticity Test}

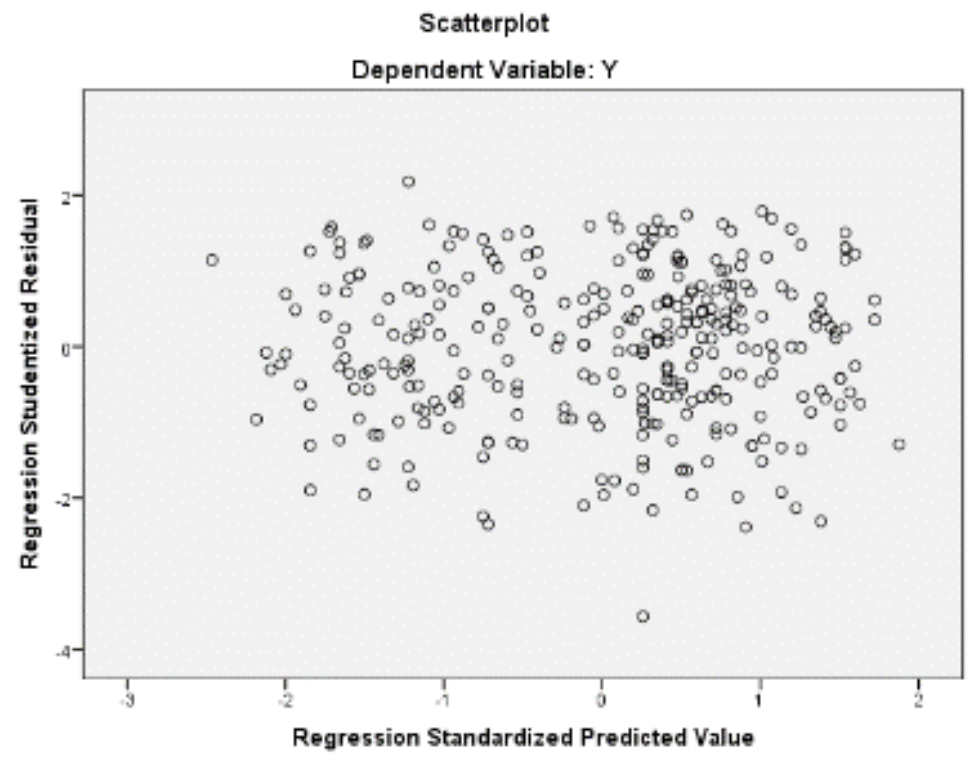

Figure 3. Heteroscedasticity Test

In this study, the heteroscedasticity test used a graph plot regression model. The results of the graph show that the points spread randomly and are scattered, both above and below the number 0 on the $Y$ axis. So, it can be concluded that the data does not occur heteroscedasticity. 


\section{Correlation Analysis}

Table 9. Correlation Analysis

\begin{tabular}{ccccccc}
\hline & \multicolumn{7}{c}{ Correlations } \\
\hline & \multicolumn{7}{c}{ GPA } & GEN & HSO & MSD & CM \\
\hline \multirow{4}{*}{ Pearson Correlation } & GPA & 1.000 & .018 & .123 & -.026 & -.035 \\
\cline { 2 - 7 } & GEN & .018 & 1.000 & -.076 & -.083 & .013 \\
\cline { 2 - 7 } & HSO & .123 & -.076 & 1.000 & .222 & .031 \\
\cline { 2 - 7 } & MSD & -.026 & -.083 & .222 & 1.000 & .085 \\
\cline { 2 - 7 } & CM & -.035 & .013 & .031 & .085 & 1.000 \\
\hline \multirow{5}{*}{ Sig. (1-tailed) } & GPA &. & .371 & .014 & .322 & .269 \\
\cline { 2 - 7 } & GEN & .371 &. & .087 & .070 & .408 \\
\cline { 2 - 7 } & HSO & .014 & .087 &. & .000 & .292 \\
\cline { 2 - 7 } & MSD & .322 & .070 & .000 &. & .065 \\
\cline { 2 - 7 } & CM & .269 & .408 & .292 & .065 &. \\
\hline \multirow{5}{*}{$\mathrm{N}$} & GPA & 320 & 320 & 320 & 320 & 320 \\
\cline { 2 - 7 } & GEN & 320 & 320 & 320 & 320 & 320 \\
\cline { 2 - 7 } & HSO & 320 & 320 & 320 & 320 & 320 \\
\cline { 2 - 7 } & MSD & 320 & 320 & 320 & 320 & 320 \\
\cline { 2 - 7 } & CM & 320 & 320 & 320 & 320 & 320 \\
\hline
\end{tabular}

Based on the table above, the GEN, HSO, MSD, CM values are $0.018,0.123,-0.26,-0.35$, it can be concluded that GEN, HSO, MSD, CM are related to GPA

The following are the results of the interpretation of the $r$ value:

Table 10. R value Test

\begin{tabular}{ccc}
\hline Variable & Relationship level & Conclusion \\
\hline GEN & 0.018 & Very Low Significant \\
\hline HSO & 0.123 & Very Low Significant \\
\hline MSD & -0.26 & Very Low Significant \\
\hline CM & -0.35 & Very Low Significant \\
\hline
\end{tabular}

The conclusion that the data obtained from the results of correlation analysis is that gender, school origin, high school major, and college motivation have a very low effect on GPA.

\section{Multiple Linear Regression Analysis}

Regression analysis was conducted to determine the relationship between the independent variable and the dependent variable. This analysis also examines the direction of the relationship from the independent variable to the dependent variable. The regression equation used in conducting regression analysis is the regression equation used in conducting regression analysis as follows:

$$
\mathrm{IPK}=\alpha+\beta 1 \mathrm{GEN}+\beta 2 \mathrm{HSO}+\beta 3 \mathrm{MSD}+\beta 4 \mathrm{CM}+\mathrm{e}
$$

\section{Coefficient of Determination (R2)}

The coefficient of determination has a value between 0 and 1 . Here are the results of the coefficient of determination analyzed using SPSS.

Table 11. Result of Coefficient of Determination

\begin{tabular}{|c|c|c|c|c|c|}
\hline \multicolumn{6}{|c|}{ Model Summary } \\
\hline Model & $\mathbf{R}$ & R Square & $\begin{array}{l}\text { Adjusted R } \\
\text { Square }\end{array}$ & $\begin{array}{l}\text { Std. Error of the } \\
\text { Estimate }\end{array}$ & Durbin-Watson \\
\hline 1 & $.141^{\mathrm{a}}$ & .020 & .008 & .51152 & 1.945 \\
\hline \multicolumn{6}{|c|}{ a. Predictors: (Constant), CM, GEN, HSO, MSD } \\
\hline \multicolumn{6}{|c|}{ b. Dependent Variable : GPA } \\
\hline
\end{tabular}


Based on the data in the table above, the adjusted R2 value is $0.008(0.8 \%)$. While the rest $(100 \%-0.8 \%$ $=99.2 \%$ ) is explained by other variables outside this study. Meanwhile, SEE (Standard Error of the Estimate) of 0.51152 indicates a regression model that is quite good in predicting GPA.

Table 12. ANOVA Test

\begin{tabular}{|c|c|c|c|c|c|c|}
\hline \multicolumn{7}{|c|}{ ANOVA $^{a}$} \\
\hline & Model & $\begin{array}{l}\text { Sum of } \\
\text { Squares }\end{array}$ & df & Mean Square & $\mathbf{F}$ & Sig. \\
\hline \multirow{3}{*}{1} & Regression & 1.678 & 4 & .419 & 1.603 & $.173^{b}$ \\
\hline & Residual & 82.422 & 315 & .262 & & \\
\hline & Total & 84.100 & 319 & & & \\
\hline
\end{tabular}

Based on the F test (ANOVA test) obtained an F value of 1.603, with a significant probability of 0.173 . F value is less than 4, then Ho is accepted, the conclusion is that not all independent variables significantly affect the dependent variable. The significant probability value is 0.173 , meaning that Ho is accepted, there is no significant effect on the GPA of the four variables used.

\section{T Test}

Table 13. T test Result

\begin{tabular}{|c|c|c|c|c|c|c|}
\hline \multicolumn{7}{|c|}{ Coefficients $^{\mathbf{a}}$} \\
\hline & \multirow{2}{*}{$\begin{array}{c}\text { Model } \\
\text { B }\end{array}$} & \multicolumn{2}{|c|}{ Unstandardized Coefficients } & \multirow[t]{2}{*}{$\begin{array}{c}\text { Standardized } \\
\text { Coefficients }\end{array}$} & \multirow[t]{2}{*}{$\mathbf{t}$} & \multirow[t]{2}{*}{ Sig. } \\
\hline & & Std. Error & Beta & & & \\
\hline \multirow{5}{*}{1} & (Constant) & 3.083 & .273 & & 11.286 & .000 \\
\hline & GEN & .027 & .060 & .025 & .449 & .654 \\
\hline & HSO & .148 & .062 & .138 & 2.401 & .017 \\
\hline & MSD & -.055 & .061 & -.051 & -.895 & .372 \\
\hline & $\mathrm{CM}$ & -.054 & .087 & -.035 & -.620 & .536 \\
\hline
\end{tabular}

From the data information, the significance value of GEN, MSD, CM is greater than 0.05 meaning that there is no significant effect on GPA, while HSO is smaller than 0.05 where SWAS has a significant effect on GPA.

The GEN variable in the research conducted by Susanti (2014) had a significant effect, but in this study, after using the $t$ test, the results showed no significant effect. This may be due to differences in the existing respondents.

\section{CONCLUSION}

\section{Conclusion}

This study aims to obtain empirical evidence of the influence of gender, school origin, high school, college motivation, on academic achievement. Therefore, based on the results of the data processing carried out using the SPSS version 20 application, the following conclusions were obtained:

1. Gender has no significant effect on the academic performance (GPA) of accounting and finance students.

2. High School Origin has a significant effect on the academic achievement (GPA) of accounting and finance students.

3. The Middle School Department has no significant effect on the academic performance (GPA) of accounting and finance students.

4. College Motivation does not significantly affect the academic performance (GPA) of Accounting and Finance students.

\section{Research Limitations}

The limitation of this research is that the data collected has a small scope, since it aims to identify and find out related to the quality of accounting education that has been carried out according to developments and 
changes. Furthermore, this research is focused on better understanding the perspectives of all students studying at one of the Indonesian universities, which is expected to update information related to accounting education.

\section{Suggestion}

Based on the research conducted, there are several suggestions that can help improve future results, namely:

1. Subsequent research can also take other dependent variables, and if you continue to use the GPA, you can use the GPA not just for the first year.

2. Motivation variables in further research can be developed not only in first year motivation, but also to be explored more deeply about current motivation.

3. Further research can be done by comparing the GPA using the GPA for the first year of college and the current GPA.

4. Make a broader scope research related to digital transformation in the formation of an accounting education model in Indonesia, which is expected to make an important contribution to empowering younger generations, who can contribute more effectively to support the economy and society of the country.

\section{REFERENCES}

Albretch. W, Sack R (2000). Accounting Education: Charting the Course through Perilous Future. USA: American Accounting Association

Aryati \& Imran. (2014). Faktor-faktor yang Mempengaruhi Prestasi Belajar Mahasiswa pada kelompok Mata Kuliah Keahlian Akuntansi. Jurnal Siwalima 13-22.

Creswell, J. W. (2007). Research Design: Qualitative, Quantitative and Mixed Method Aproaches. SAGE Publications. https://doi.org/10.4135/9781849208956

Frey, C. B., \& Osborne, M. A. (2017). The future of employment: How susceptible are jobs to computerisation? Technological Forecasting and Social Change. https://doi.org/10.1016/j.techfore.2016.08.019

Ghozali, I. (2012). Aplikasi Analisis Multivariate Dengan Program IBM SPSS 20. Edisi 6

Hanafi, M. A. O., \& Fadilah, P. (2017). Quantitative Data Analysis: Choosing Between SPSS, PLS and AMOS in Social Science Research. International Interdisciplinary Journal of Scientific Research, 3(1), 14-25.

Lalima, D., \& Lata Dangwal, K. (2017). Blended Learning: An Innovative Approach. Universal Journal of Educational Research. https://doi.org/10.13189/ujer.2017.050116

Lee, J., Lim, C., \& Kim, H. (2017). Development of an instructional design model for flipped learning in higher education. Educational Technology Research and Development. https://doi.org/10.1007/s11423-0169502-1

Octaryani, M., \& Baidun, A. (2018). Uji Validitas Konstruk Resiliensi. Jurnal Pengukuran Psikologi Dan Pendidikan Indonesia (JP3I). https://doi.org/10.15408/jp3i.v6i1.8150

Priatna, B. A. (2008). Instrumen penelitian. Jurnal Pendidikan Matematika.

Raguseo, E. (2018). Big data technologies: An empirical investigation on their adoption, benefits and risks for companies. International Journal of Information Management, 38(1), 187-195. https://doi.org/10.1016/j. ijinfomgt.2017.07.008

Rezaee, Z., \& Wang, J. (2019). Relevance of big data to forensic accounting practice and education. Managerial Auditing Journal. https://doi.org/10.1108/MAJ-08-2017-1633

Robbins, Stephen T.A (2013). Organizational Behavior. USA : Pearson

Santrock J.W. (2009). Psikologi Pendidikan. Edisi 3 Buku 1. (D.Angelica Trans). Jakarta: Salemba Humanika

Santrock, J.W. (2011). Educational Psychology. NewYork :McGraw-Hill 
Sarjono, H. Julianita (2011). SPSS vs Lisrel. Jakarta: Salemba Empat

Sekaran, R.B (2013).Research and Methods for Business. United Kingdom : WILEY

Sorescu, A. (2017). Data-Driven Business Model Innovation. Journal of Product Innovation Management. https:// doi.org/10.1111/jpim.12398

Sugiyono. (2015). Metode Penelitian Pendidikan. Bandung. In Metode Penelitian Pendidikan (Pendekatan Kuantitatif, Kualitatif, dan R\&D).

Weygandt Jerry, Kimmel Paul, Kieso Don. (2011). Financial Accounting IFRS Edition. United Stated: John Wiley \& Sons, Inc. 